\title{
Beppe Fenoglio's I ventitre giorni della città di Alba- Personal Memory and Reflections on Civil War
}

\author{
Christoph Söding \\ Humboldt-Universität ₹u Berlin
}

\begin{abstract}
:
The article examines I ventitre giomi della città di Alba, one of Beppe Fenoglio's early texts about the Italian resistance during the Second World War. Largely ignored at the time of its first publication, it rose to fame only in the 1960s. This is strongly linked to the fact that Fenoglio depicts the resistance as a civil war, a rather controversial issue in post-war Italy. He deheroises the partisans and shows the inadequacy of social categories by adopting a specific narrative strategy that focuses on the mundane and the ridiculous.
\end{abstract}

Keywords: Resistenza, narrative, comic, historiography, post-war Italy

Fenoglio's short story I ventitre giorni della città di Alba (1952) depicts the partisan siege of the small town of Alba in Piedmont, Fenoglio's birthplace, that took place in 1944 and lasted for exactly 23 days. The reader is provided with a precise timeframe for the episode from the outset of the story, which also declares the massive losses that the partisans had to suffer: "Alba la presero in duemila il 10 ottobre e la persero in duecento il 2 novembre dell'anno 1944" (3). The sentence expresses a circularity, which is reflected in the narrated plot. After a good three weeks under partisan rule, almost everything in Alba goes back to the way it used to be: the Fascists have regained control and life in the city resumes its usual course. The partisans have been pushed back into the hills of the region - having, however, paid a huge price.

The Resistenza - the Italian Resistance movement that fought against the Fascist Republic of Salo, which continued the fights of the Second World War with the help of the German troops in northern Italy - became an important founding element of the Italian left (Natoli 307-327) and indeed of Italian society as such (Miller 39-43) after the war. Many political figures of the Communist and Socialist parties as well as journal and newspaper editors and contributors had gained experience within the Resistance. Many historians and politicians have tried to evaluate the Resistance, oftentimes pursuing a political appropriation for their own interests (Miller 37-45).

Besides the political and historiographical accounts, there is also an abundance of literary and cinematic material dealing with the Resistance. From Rossellini's Roma, città aperta (1945) and Elio Vittorini's Uomini e no (1945) immediately after the war to Italo Calvino's Il sentiero dei nidi di ragno (1947) and Ultimo viene il corvo (1949) continuing into the 1950s (Fenoglio, I ventitre giorni della città di Alba, 1952; Bassani, Cinque storie ferraresi, 1958) and the 60s (Bassani, Il Giardino dei Finzi-Contini, 1962; Fenoglio, Il Partigiano 
Jobnny, 1968), just to name a few: there is no lack of reports from the era not long past, which are mostly rather personal in nature.

As early as 1949, however, Italo Calvino had observed that not one of the texts or films was able to depict the Resistenza as a whole (Calvino, Resistenza 91). He only revised this judgment 15 years later, in 1964, adding that Beppe Fenoglio was the only writer who had been able to describe the Resisten za "proprio com'era, di dentro e di fuori, vera come mai era stata scritta" (Calvino, "Presentazione" XXIII; Cellinese 40 f.). This approach has later been called a "vigorous realism" (de Souza 54), that is to say, an attempt at providing a factual yet subjective representation of that period. Already at first glance, we can observe that Fenoglio was focused on providing accurate historical facts and dates (de Souza 55 f.). The value of this accuracy can be shown by the fact that for example (but not only) Renzo De Felice uses Fenoglio's narrative texts as historical sources in his comprehensive compendium about the years 1943-1945, which forms part of his extensive biography about Mussolini (De Felice 126, $332 \mathrm{ff}$ ). This tendency can be traced back to Calvino as well, who saw in Fenoglio's novel La paga del sabato a "documento della storia di una generazione" (Isella VI).

In this paper it is my aim to show that I ventitre giorni della città di Alba and Fenoglio's other texts are important means of understanding historical events not despite their being literary works, but exactly because of it. They invert the characteristics usually ascribed to the two genres of fiction and historiography, namely the first having creative freedom and the second being factually accurate. Fenoglio understood that the historiographic accounts of the Resistenza idealised the past and thus could not provide a true picture of it. His vigour for realism, on the contrary, leads to a de-idealisation of war by means of describing the ordinary, the un-heroic. It is only by means of this strategy that the conflict on Italian soil between 1943 and 1945 could be spoken of as a civil war, acknowledging the fact that Italians fought on both sides - a rather problematic aspect of post-war Italian reconciliation efforts (Miller 39-43) - and that neither of them were heroes. I will, to this end, start out with some reflections on narration and historiography, before tracing the depiction of the un-heroic, the ordinary and the absurd in Fenoglio's texts.

It has been identified as a problem of the Italian intellectual left at the time in general and of the resistance against the Fascists in particular that it was predominantly Marxist-materialistic and that it did not recognise the main reason for the rise and the success of the Fascists, namely the ability to stir fear within the population. Carlo Levi had already seen this before the war and had taken a psychological approach to explaining Fascism in his essay Paura della libertà (Gasperina 31-37). I think that Fenoglio's narrative works can be seen in this context as well. His texts border historiography, they analyse the recent past and offer explanations - albeit implicit ones - for the divide in the Italian post-war society.

Hayden White, in his 1973 book Metahistory, famously develops the notion that the historian's work is always of a poetic and narrative nature. By establishing relationships between events and by hierarchising their relevance, the historian transforms a series of events into a "story" with a beginning, a middle part, and an ending (White, Metahistory $5 \mathrm{f}$.). White defines

the historical work as what it most manifestly is - that is to say, a verbal structure in the form of narrative prose discourse that purports to be a model, or icon, of past structures 
and processes in the interest of explaining what they were by representing them (White, Metahistory 4).

In this sense, Fenoglio's I ventitre giomi della città di Alba can, or indeed has to be considered a historical work. It represents a past process in narrative prose and thereby explains it to the readers. Even if we consider that historical works are understood as depicting "the truth" while literary works are perceived to be fictional, and concede that Fenoglio's historical accuracy might falter on the level of minor details (the narrator for example talks about eight prostitutes on duty in the brothel of Alba (5) - for the course of the story, however, it is not important whether there really were eight or seven or nine), I ventitre giomi still offers a realistic account and gives the readers an explanation of "past structures and processes". It is also in line with the specification White made in his 1984 essay "The Question of Narrative in Contemporary Historical Theory", where he addresses the problematic relationship between historiography and literature and states that

what distinguishes 'historical' from 'fictional' stories is first and foremost their contents, rather than their form. The content of historical stories is real events, events that really happened, rather than imaginary events, events invented by the narrator (White, "Question" 2).

This is, of course, rather simplistic and fails to acknowledge theoretical approaches to defining literary vs. non-literary texts that have been developed in the course of the $20^{\text {th }}$ century. It also only works ex negativo: following White's line of argument, 'historical stories' would seem to be defined in opposition to those that treat invented events, although one might easily imagine a text containing accounts of real events, without by any means pertaining to historiography.

And yet, Fenoglio's text seems to lie on the boundary between historiography and literature. If "History is art, not science", as James Miller put it (Miller 38), then $I$ ventitre giorni could also be considered a work of historiography. There is no protagonist in the traditional sense, there are not even any single characters that the reader can follow and no names are being used. It is, however, not only a historical account but also a literary text, a narrative about a period in the history of the city of Alba. This becomes apparent when considering the aesthetic configuration of the text. The dramatic incipit, which foreshadows the whole course of action, is one example; the narrator's detached-ironic perspective is another one. There are also references to the Italian literary tradition, such as the sigh "Ahi, povera Italia!" (5), which the narrator has a person in the crowd mutter. It refers to a centuries-long patriotic discourse about the decadent state of Italy originating in Dante, in which the likes of Petrarch, Alfieri, and Leopardi took part (Thoma 69-80). These kinds of references are atypical for works of historiography.

\footnotetext{
${ }^{1}$ In his understanding of the discipline of historiography, Miller concurs with Hayden White. The latter traces the origins of his argument back to Benedetto Croce, who both in "La storia ridotta sotto il concetto generale dell'arte" (1893) and in Teoria e storia della storiografia (1917) argues that there are living and lifeless accounts of events (Croce, Teoria, $11 \mathrm{ff}$.) and that only the former are "storia vera" because they can be and are narrated (Croce, "Storia" 38).
} 
By writing a work of literature, Fenoglio has the freedom of choice. It is up to the author to decide which parts of the events to include and which to exclude, which periods to summarise quickly and which to go into more thoroughly. It is these details that are at the heart of Fenoglio's narration and that make it possible to extrapolate a more universal picture of the historical period. The short-lived free Republic of Alba stands for other partisan entities in other places. Ettore represents other partisans who have trouble reintegrating into society. The general image, the "documento della storia di una generazione" (Isella VI), as Calvino put it, is constructed on the one hand from the combination of the different single elements - just like reading the twelve short stories of the collection leads to an overall picture of the society of the Langhe at that time - and on the other hand by extending or generalising the particular cases - Ettore is not the only partisan with integration issues, and Raoul is not the only young man who has difficulty finding his way into the group of the partisans.

Therefore, I ventitre giomi has the advantage of not having to immediately put forward a political standpoint. It does not have to commit to a Weltanschaunng that might be considered ideological. It thus facilitates the civil discourse because it offers a complete picture of the events but under the premise of taking a personal perspective and being a personal memory. It is the fact of being a personal memory that lends the account its credibility and authority. Furthermore, the personal memory is not generalised into an ideology. It offers an authentic perspective on the events and leaves the generalisation to the reader.

By taking a subjective vantage point, which is at the same time rich in detail, $\mathrm{Fe}$ noglio helps the Italian society break the stalemate of the competing interpretations of history. He does not write history, but he narrates stories; he does not claim to be objective or to have encountered a final assessment, but he offers single stories from the point of view and with the experience of a contemporary witness. He does not propose a normative evaluation system but depicts the parties that are involved from their human, flawed, side. His approach is individual, not ideological. Fenoglio's personal memory undergoes a transformation; it comes to represent the experiences of others and as such becomes a medium that allows the author to speak analytically about the civil war.

In all this, Fenoglio is of course not impartial. This is very easily proven by the observation that his stories are all about the partisans and not about the Fascists. His partisans, however, as will be shown, are no heroes, but are a very diverse group of normal persons with errors, fears and flaws. This approach did not catch on with the public at the time and in an Italian society that was in a state of trauma and denial. It is therefore not surprising that the commercial success of Fenoglio's texts began only after his death in the early 60s. Furthermore, it explains the phenomenon that his literary texts were used as sources and references by historiographers - especially by those who call the period from 1943 to 1945 in Italy what in fact it was, namely a civil war.

It is very interesting in this context to look at the techniques Fenoglio employs to achieve his aim. He presents the reader with a world full of anti-heroes, human error and deficits, and thus positions himself explicitly against a traditional or classical style of describing warfare in terms of heroism. In this manner, he even counteracts the efforts or tendency to ascribe a heroic status to the partisans. The partisans the reader meets in the story wear ridiculous uniforms, have no idea about warfare, are vain and 
care more about the timing of their lunch break than about the imminent attack of the Fascists. This is, of course, in part due to the fact that most of them are underage and have no previous military experience. In the detail, these descriptions seem bizarre: "molti di quei minorenni che, per non aver mai voluto tirare alle galline, non avevano mai sparato il fucile, si domandavano ora se sparare poteva essere complicato e se il colpo faceva male alle orecchie" (12). The narrator contrasts the classical motif of the night before the battle and the hero carefully preparing himself and his weapons for the fight with the naivety and the youthfulness of the partisans of Alba, which stirs an almost comical effect. These young men and women are no normal soldiers. They have neither the equipment nor the training, and the majority of them are not even ready to risk their own lives in the fight. This is not only illustrated by their fear of losing their hearing, but also by constant desertions, or by small comments and observations like "E s'addormentò anche qualche sentinella" (12).

Similar observations can be made about the "borghesi", the normal citizens, and about the Fascists. During the previously negotiated retreat from the city, the soldiers of the Republic are still anxious that some of the partisans might shoot them in the back. That is why time and again those at the back will accelerate a little, just to avoid being the unlucky one hit by a possible bullet. These same soldiers then turn around after the retreat and yell back in the direction of the city of Alba and the partisans: "Venduti, bastardi e traditori" (3). The reader also learns a lot about the normal citizens of Alba in this regard. Some of them just leave quietly before the upcoming fight ("Una parte dei borghesi lasciò la città dicendo ai vicini che andavano a passare un po' di giorni in campagna, e nessuno si ricordò d'obiettare che non era più la stagione” (7)), others do not bother to evaluate the parties of the war according to ideological viewpoints, but simply by their capacity to organise the everyday problems of the city - and reach a preference for the Fascists.

Finally, there is a short comment by the narrator that is very illuminating. He mentions that despite all the imponderabilia before the deciding battle two things are clear: namely that firstly the Fascists will attack at dawn, and that secondly they will use a certain bridge to cross the river. The partisans have never been able to occupy or destroy that bridge because the Germans reside in a nearby castle and they are in "numero sufficiente per infischiarsi di tutti i partigiani delle Langhe" (11). It is in those tiny comments that Fenoglio leads the reader towards an assessment of the situation. The Germans do not even participate in the fight; they do not seem to care about the conflict between the Italian partisans and the Italian Fascists, and if they did, they could easily win. The protagonists of those conflicts, in turn, are reduced to naïve anti-heroes, to second-class soldiers, who carry out their skirmishes, but who do not stand a chance once things get serious. The real power of the German and Italian Fascist armies is revealed to the partisans when they leave the town after their defeat and pass by some armoured tanks that had not even been used in the battle.

Adding numerous small remarks and observations like the one cited above, the narrator's voice becomes more and more prominent and almost gains the status of a character. While the remarks are omniscient, they focalise different aspects as the narration progresses, to guide and to present the readers with a certain attitude. Their tone is benevolent, often amused, and can be compared to that of Manzoni's narrator in the Promessi sposi, albeit being more melancholic and darker because of the more violent historical background. The similarity will be apparent to any Italian reader, given the 
huge and constant popularity of Manzoni's novel. It is in the narrator's voice that most of the comedic elements reside. Their function is to serve as a medium to convey realism. The heroic and the comedic are oppositional terms insofar as comedy is an expression of the mundane. A hero is someone who stands above normality, who is not to be perceived as doing everyday tasks. The depiction of heroism is a perception filter that blocks out trivial actions, which is why we never see James Bond signing insurance papers or filing taxes. The hero exists only in the eyes of the perceiver and by means of a construction. There can be no room for vulnerability or even normality. Of course, this is a dichotomy that can be traced back as far as to Aristotle's Poetics and his distinction of the tragic - depicting "heroic action" - and the comic - starring "inferior people" (Aristotle 1449a-b). Its implications are still being used by public figures in all parts of society today - be it politicians, actors, or other artists, who create a public image of themselves.

The same mechanisms are at work when we reflect on historical periods and events. There can be a tendency to idealise, especially with regard to foundational moments of nations or of political factions. By depicting the human, vulnerable, insecure and naïve traits of the Resistenza fighters and their opponents, Fenoglio counteracts any effort to idealise that period. In so doing, he stands in the tradition of the pre-war Italian intellectual left. It was Antonio Gramsci who famously described the Italian Risorgimento, the national unification movement, as failed and thus acknowledged that the efforts made throughout the $19^{\text {th }}$ century to construct a national unity for Italy by first obtaining a cultural identity had not been successful (Gramsci, Il Risorgimento). The writers and intellectuals of the Risorgimento had predominantly sought to answer the question of how cultural identity might be achieved within the clearly defined geographical unit of the Italian peninsula, which was culturally and politically diverse (Banti 66). Ugo Foscolo had invoked the cenotaphs in Santa Croce in Florence as examples of Italy's past glories (Dei Sepolcri, 1807; Ultime lettere di Jacopo Ortis, 1816); Giacomo Leopardi had made reference to the Battle of Thermopylae as an analogy to an Italian population faced with an overwhelming amount of foreign suppressors (All'Italia, 1818). In the wake of Manzoni's Promessi sposi a number of historical novels were published that presented young, daring, chivalrous characters who were supposed to display the exemplary behaviour of good Italians (Massimo D'Azeglio, Ettore Fieramosca, 1833; Tommaso Grossi, Marco Visconti, 1834). This line of thought continued after the political unification in 1860 with the very famous children's book Cuore (1886) by Edmondo de Amicis. The late $19^{\text {th }}$ century even saw the return of a classicist taste in literature as best exemplified by Gabriele D'Annunzio; and Filippo Tommaso Marinetti made the heroic self-stylisation a defining feature of the Futurist movement.

While there are notable aesthetic differences between the mentioned texts and currents, they all represent variations of the heroic. The underlying idea is that heroism can have an integrating effect for society. It is this top-down approach that Gramsci resents when he criticises the Risorgimento as being primarily influenced by the nobility and the bourgeoisie and when he calls Manzoni's depiction of the lower classes "condescending" (Gramsci, Letteratura e vita nazionale 73). There are, of course, literary currents in Italy that repudiate this form of heroism as well. The Scapigliatura in the 1860s and 70s and the Crepuscolari from the turn of the twentieth century tried to find a simpler poetic language than their decadent-classicist counterparts Pascoli and D'Annun- 
zio, as did poets like Giuseppe Ungaretti (Allegria di naufragi, 1919) and Eugenio Montale (Ossi di seppia, 1924) after World War I, who acknowledged the traumatic experience of the war and its effects on the personal development of young men.

Gramsci, of course, did not write literary texts. His political and philosophical views, however, became very influential for the Italian left as a whole, including authors before and after the war. It seems safe to say that Fenoglio's texts echo Gramsci's criticism of positivistic assertions of what Italians should be like, which are conveyed via depictions of heroism. He radicalises the idea insofar as he extends it to the political left: not even partisans can be heroes for Fenoglio, because describing them as such would entail an idealisation which in turn leaves room for political instrumentalization and a falsified version of history.

A second aspect of Fenoglio's texts is that they illustrate the absurdity and the social implications of this conflict, which in fact was a civil war. The term 'civil war' as a description of the conflict between the Resistenza and the Fascist Republic of Salo was established in academic discourse only in the early nineties by the historian and time-witness Claudio Pavone (Una guerra civile) and remains disputed to the present day (Natoli 321). The commendable first historical study of the Resistenza by Roberto Battaglia from 1953, on the contrary, follows the predominant interpretation of the Italian left at the time, namely to understand the Resisten $a$ as an incident of class struggle. Interestingly enough, the term 'Resistenza' itself only came into common use in the historical period following the events it refers to. The actual mode of speaking at the time revolved around the word "liberazione", as is shown on the one hand by the name of the Comitato di Liberazione Nazionale (CLN), the organised resistance against the Fascist republic, and on the other hand by the widely used expression "movimento di liberazione" (Pavone 447). An exception to this is, in fact, Fenoglio, who had first published parts of his collection in 1949 with the title Racconti della guerra civile and changed the title to its current form only in 1952.

Eduardo Saccone has shown that Fenoglio in his narrations of the war (I ventitre giorni della città di Alba and his novel Il partigiano Johnny) is focused on depicting war as an act of resistance (Saccone 36 f.). ${ }^{2}$ This resistance, in turn, is never defined positively as a fight for something, but always as a fight against something. In this sense, the war waged by the protagonists in Fenoglio's stories is not a fight for the Italian fatherland against Germany, but the resistance against Fascism in Italy. This differentiation is important for understanding the absurdity of the fights taking place in Fenoglio's texts. The relevance of the motif of absurdity in other works by Fenoglio has been shown by Yannick Gouchan's analysis of the author's narrations about the First World War (Gouchan 93-115). Gouchan (109 ff.) has also exposed the strong connection between the soldiers of the First and the partisans of the Second World War within Fenoglio's work.

The concrete absurdity of the fight for Alba on November $2^{\text {nd }}, 1944$, is made clear from the outset. None of the two parties really wants to risk their lives and there is no intrinsic motivation whatsoever to conduct the battle: "I fascisti non vollero dire che non avevan voglia di riprendersi Alba con la forza, i partigiani non vollero dire che non si sentivano di difenderla a lungo, e da queste reticenze nacque la battaglia di Alba"

2 Already 20 years before Saccone, Massimo Lardi had identified a series of oppositional pairs as constants that define Fenoglio's work: life-death, imprisonment-liberation, movement-inertia, etc. 
(10). Nobody wants to fight, but there will be a battle, which is mostly owed to a diffuse feeling of honour, pride and expectations.

Another illustration of the strangeness of this conflict is a short insertion just before the ending of the description of the battle. After having reported how the partisans are preparing themselves for the incumbent attack and after having described specific battle episodes from the vantage point of the single partisan groups, the narrator makes it clear that the partisans stand no chance of defending the city, because the promised reinforcements will not materialise. He explains:

In quel medesimo giorno, a Dogliani ch'è un grosso paese a venti chilometri da Alba, c'era la fiera autunnale e in piazza ci sarà stato un migliaio di partigiani che sparavano nei tirasegni, taroccavano le ragazze, bevevano le bibite e riuscivano con molta facilità a non sentire il fragore della battaglia di Alba (17).

Of course, this can be understood as a bitter reckoning of Fenoglio's with his former combatants. It shows, however, the lack of a complete mobilisation of society, the majority of which escapes the horror of the civil war by attending a local fair and thus ignoring the obvious. Life continues as normal in many places, and it is not only the "borghesi" that are exposed to this accusation, but also the partisans themselves.

In addition to descriptions of normality in contrast with the heroism of battle scenes at the core of a civil war, Fenoglio's other short stories also shed some light on different aspects of daily life during the period. Two examples can illustrate this point. In Gli inizi del Partigiano Raoul, the readers get to know a young man who has decided to join the partisans about ten months after the beginning of the civil war. He is a student, an intellectual, who up to that point has been living with his mother and is plagued by his own conscience because of not having joined the fight sooner. His thoughts and emotions alternate between the wish to fit in, to belong, and the fear of rejection - a feeling that he compares to his first day at university - and the fear of death in combat, of course. In a certain way, this is a coming-of-age-story, which however is narrated very densely and covers just a little less than 24 hours. It shows how normal, everyday patterns and social mechanisms continue to work during the civil war. What is different here from I ventitre giorni della città di Alba is the focus on one character. The internal focalisation gives the readers a unique yet exemplary perspective on a situation many people can relate to. In the end, it is the protagonist's dream about being arrested, and ultimately shot, by Fascists that helps him integrate into the group. The short story ends with Raoul laughing about it together with a fellow partisan, whom he had previously detested.

Another insight into a personal experience related to the civil war is offered by Ettore va al lavoro. The protagonist is a highly decorated partisan who was well known during the war. At the time the narration takes place, however, after the war, he struggles with readjusting to society. His accomplishments during the war are sharply contrasted with his current existence. He is once again dependent on his parents who urge him to finally pick up a job and contribute to the household. Ettore explains his incapacity - or unwillingness - to take a job by referring to his past: "Io non mi trovo in questa vita perché ho fatto la guerra. [...] la guerra mi ha cambiato, mi ha rotto l'abitudine di questa vita qui" (94). As an explanation for leaving a post in a factory, he states: "Io da partigiano comandavo venti uomini e quello non era un lavoro per me" 
(Fenoglio, "Ettore" 95). The treatment of Ettore is emblematic of many other similar fortunes: the achievements in and for the Resistenza are not being rewarded, norms and standards have changed. Ettore expects gratitude and respect, but is confronted with a mere expectation to carry on with normal life and to earn some money. There is no reflection of what has happened - neither on a personal nor on a social level. For this reason, Ettore in this story is unable to overcome his inner unrest, his longing for an extraordinary life. He rejects a secure and stable job by repeating his usual phrases: "Io avrò un destino diverso dal vostro" (Fenoglio, "Ettore" 102) and hires himself out to a fellow ex-partisan who is engaged in illegal contraband trade. The fact that in the very end of the short story he grabs his pistol in order to "go to work" shows the difference between Ettore's world and regular life - a difference which is still present and cannot be overcome.

All of these examples show how Fenoglio captures the mundane, quotidian aspects of the Resistenza and the civil war. His protagonists are no heroes but experience problems at all stages of the war, from integrating into a partisan group, to being mentally and physically prepared for battle, to readjusting to society afterwards. While traditional depictions of heroism exclude everything mundane and construct a persona or a myth that is based on select parts of who the person really is, Fenoglio does the exact opposite. He puts the mundane in the foreground, emphasising the protagonists' human side, their weaknesses and inconsistencies. This approach to writing about war is not altogether new, of course, but it helps make the discourse less overloaded with political terms and divisive ideology and thus facilitates speaking about its horror. Paradoxically, the individual perspective fosters the rationalisation of discourse.

There are, of course, many other texts and films about the war in Italy and about the Resistenza in particular created in the 1940s and 1950s. It is a trademark especially of neorealist film, but also of literature at the time, to remove anything artificial and to show things as realistically as possible. Rossellini in his neorealist trilogy, for example, uses original locations like the destroyed Berlin of Germania anno zero (1948) or Rome in Roma città aperta (1945) and lay actors in Paisà (1946). Of all the neorealist films of that era that focus on aspects of the war and the Resistenza, it is perhaps Roma città aperta that is most comparable to I ventitre giorni della citta di Alba, since it also shows the complexity of problems within the Italian society in the last years of the war. The resistance is everything but united because its members come from very diverse social and political backgrounds, and it is the collaboration of an Italian woman which leads to the capture and eventual execution of the protagonists. There is, however, no absurd or comedic level in this film. Comedic currents in film like neorealismo rosa and commedia allitaliana in turn, which both develop from the late 1950s onwards, are less political in general (Rushing 7 f.).

There is an extensive literary production from the 1940s, 50s and even 60s about the Resistenza by authors like Elio Vittorini, Italo Calvino, Vasco Pratolini and others. Their successful novels and short stories are often influenced by the authors' biographies and hence focus on the problematic relations of an individual with society. Enne 2, the protagonist of Vittorini's Uomini e no (1945), has to come to terms with his role as a leader of a group of partisans as well as his impossible love for a married woman, Pratolini's Cronaca familiare (1947) centres around the difficult relationship of the author's alter ego Vasco with his brother, and Calvino's first novel Il sentiero dei nidi di ragno (1947) has 10-year-old Pin as a protagonist, who is surrounded by grown-ups 
whose behaviour he struggles to understand. This last text has some comic effects, which arise from the discrepancy between the boy's naïvete and the readers' knowledge about what is going on, e.g. when Pin's sister has soldiers visiting her at night time because she is a sex worker, or when there is romantic jealousy involving the partisan group's leader and his girlfriend. The mentioned texts, however, are stories about individual experiences and only briefly and subtly touch upon the larger societal questions.

This is what separates Fenoglio from other texts about the Resistenza. I ventitre giorni della città di Alba does not have a protagonist; it does not even provide the names of any of the characters. Thus, the individual experience is put out of focus and is replaced by an overview through the eyes of the narrator. It is exemplary not in the sense that it narrates an individual story that could be taken to reflect many others, but rather as an excerpt of society that also represents its other parts and, indeed, Italian society as a whole. This almost historiographic approach which describes the Resistenza as a civil war is achieved by means of showing the mundane, unheroic aspects of the Resistenza. It is, at the same time, the reason why Fenoglio was largely disregarded as a writer in his lifetime, and came to fame only posthumously, when the notion of the late phase of World War II in Italy being a civil war became more widely recognised.

\section{References}

Aristotle. Poetics. Trans. Anthony Kenny. Oxford: Oxford University Press, 2013.

Banti, Alberto Mario. La nazione del Risorgimento. Turin: Einaudi, 2011.

Battaglia, Roberto. Storia della Resistenza italiana. Turin: Einaudi, 1953.

Calvino, Italo. "La letteratura italiana della Resistenza". Neorealismo: Poetiche e polemiche. Ed. Claudio Milanini. Milan: Il Saggiatore, 1980. 91-98.

Calvino, Italo. "Presentazione." Il sentiero dei nidi di ragno. Milan: Mondadori, 1993. vxxv.

Cellinese, Anna. "La Resistenza di Beppe Fenoglio nel paesaggio delle alte langhe piemontesi". Carte italiane 18 (2003): 40-58.

Croce, Benedetto. "La storia ridotta sotto il concetto generale dell'arte". Atti della Accademia pontana 23 (1893): 13-44.

Croce, Benedetto. Teoria e storia della storiografia. $2^{\text {nd }}$ ed. Bari: Laterza, 1920.

De Felice, Renzo. Mussolini l'alleato, vol. 2. La guerra civile 1943-1945. Turin: Einaudi, 1997.

De Souza, Carlos Alberto. “Analisi riassuntiva del libro ,I ventitre giorni della città di Alba' di Beppe Fenoglio". Revista de Letras 7 (1984): 53-63.

Fenoglio, Beppe. "I ventitre giorni della città di Alba". I ventitre giorni della città di Alba: I racconti barbari della Guerra civile. Ed. Dante Isella. Turin: Einaudi, 2006. 3-18.

Fenoglio, Beppe. "Ettore va al lavoro". I ventitre giorni della città di Alba. Ed. Dante Isella. Turin: Einaudi, 2006. 92-110.

Fenoglio Beppe. "Gli inizi del Partigiano Raoul”. I ventitre giorni della città di Alba. Ed. Dante Isella. Turin: Einaudi, 2006. 40-57. 
Gasperina Geroni, Riccardo. Il custode della soglia. Il sacro e le forme nell'opera di Carlo Levi. Milan: Mimesis, 2018.

Gouchan, Yannick. "L'anti-soldat dans les récits de Un Fenoglio alla prima guerra mondiale de Beppe Fenoglio". Italies 19 (2015): 93-115.

Gramsci, Antonio. Il Risorgimento. Gaeta: Ali Ribelli, 2019.

Gramsci, Antonio. Letteratura e vita nazionale (Dai Quaderni del carcere). Turin: Einaudi, 1974.

Isella, Dante. "Presentazione". I ventitre giorni della città di Alba. By Beppe Fenoglio. Ed. Dante Isella. Turin: Einaudi, 2006. v-x.

Lardi, Massimo. Opposizioni e scontri di opposti nell'opera di Beppe Fenoglio. Poschiavo: Menghini, 1976.

Levi, Carlo. Paura della libertà. Id. Scritti politici. Ed. David Bidussa. Turin: Einaudi, 2001.

Miller, James Edward. "Who chopped down that cherry tree? The Italian Resistance in history and politics, 1945-1998". Journal of Modern Italian Studies 4 (1999): 37-54.

Natoli, Claudio. "Antifaschismus und Resistenza in der Geschichte des italienischen Einheitsstaats". Faschismus und Gesellschaft in Italien. Staat Wirtschaft Kultur. Ed. Jens Petersen and Wolfgang Schieder. Cologne: SH-Verlag, 1998. 307-327.

Pavone, Claudio. Una guerra civile. Saggio storico sulla moralità nella Resistenza. Turin: Bollati Boringhieri, 1991.

Rushing, Robert A. "Planes, Trains, Automobiles, Bicycles, Spaceships, and an Elephant: Images of Movement from Neorealism to the commedia all'italiana". California Italian Studies 7 (2017). Web. 16 Dec 2020.

Saccone, Eduardo. "War and Peace in Beppe Fenoglio's Partisan Novels" MLN 111 (1996): 31-37.

Thoma, Heinz. "Italia mia". Siamo una nazione? Nationales Selbstverständnis im aktuellen Diskurs über Sprache, Literatur und Geschichte Italiens. Ed. Sabine Schwarze. Tübingen: Stauffenburg, 2006, 67-85.

White, Hayden. Metahistory. The Historical Imagination in 19th-Century Europe (40th Anniversary Edition). Baltimore: Johns Hopkins University Press, 2014.

White, Hayden. "The Question of Narrative in Contemporary Historical Theory." History and Theory 23 (1984): 1-33. 